RESEARCH PAPER

\title{
"Keep a low profile": pesticide residue, additives, and freon use in Australian tobacco manufacturing
}

\section{S Chapman}

Tobacco Control 2003;12(Suppl III):iii45-iii53

Correspondence to: Professor Simon Chapman, School of Public Health, University of Sydney, Building A 27, Sydney, NSW 2006, Australia; zsimonchapman@ health.usyd.edu.au

Professor Chapman is also Associate Direcor VicHealth Centre for Tobacco Control

Objectives: To review the Australian tobacco industry's knowledge of pesticide residue on Australian tobacco and its policies and practices on resisting calls by tobacco control advocates that consumers should be informed about pesticide residue as well as additives.

Methods: Review of previously internal industry documents relevant to pesticides and additives in Australian tobacco located from the Master Settlement Agreement websites.

Results: Between 1972 and 1994 Philip Morris Australia was aware that its leaf samples were often contaminated with pesticide residue, sometimes including organochlorine levels described by PM's European laboratories as being "extremely high". Consumers were not advised of the contamination nor products withdrawn. From 1981, the industry also resisted calls to declare fully the extent of use and long term safety data on all additives used in their products. They developed standard public responses that were evasive and misleading and, in 2000, implemented voluntary additive disclosure which allowed the companies to continue to avoid disclosure of any ingredient they deemed to be a trade secret. There was extensive use of ozone depleting freon in Australian tobacco manufacturing. Again, the industry kept this information away from consumers.

Conclusions: Australian smokers are unable to make informed decisions about smoking because pesticide and additive disclosure remains voluntary. The Australian government should regulate tobacco to require full disclosure including information on the likely health consequences of inhaling pesticide and additive pyrolysis products.

W hen smokers purchase cigarettes, many probably imagine that they are simply buying tobacco leaf rolled in paper. Few smokers are likely to be aware that the products they buy are often much more than simply tobacco and paper. They are often true "chemical cocktails"highly processed concoctions designed by tobacco industry chemists who add both natural and synthetic chemicals for a variety of reasons, including:

- to make the smoking sensation "taste" or feel better ("mouth feel")

- to make the smoke less irritating to smokers' mouths and throats, particularly to novice smokers

- to increase the efficiency with which nicotine and artificial nicotine analogues reach the brain to maximise addiction ${ }^{2}$

- to regulate the burn temperature, ${ }^{3}$ to prevent the cigarette from going out when not being inhaled, and to prevent the tobacco "sparking" and sending cinders onto smokers' clothing

- to reduce the smell of environmental tobacco smoke ${ }^{4}$

- to retain optimum moisture in the tobacco-important for storage-via the use of humectants.

A primary concern among tobacco industry chemists is to maximise nicotine dependency among users so that experimental, occasional smokers more rapidly develop into dependent regular users who consume more tobacco than they might otherwise, ${ }^{56}$ and who find it more difficult to quit ("our aim is to move Red and Special Mild as close as possible to the USA. blend and thus make it harder for existing smokers to leave the product" $).{ }^{7}$ Because this is such a fundamental preoccupation within the industry, future papers by our group will be devoted to exploring evidence about this manipulation.

This paper reviews revelations in internal tobacco industry documents about substances found in tobacco other than nicotine and nicotine analogues, with reference to the Australian tobacco industry. The first part examines pesticides known by the industry to remain in manufactured tobacco when sold to consumers. The second part examines additives used in tobacco manufacturing, and the efforts of the industry to keep this information from consumers. Historically, the tobacco industry has strongly resisted efforts to inform consumers about what it adds to tobacco in the manufacturing process.

\section{METHODS}

The documents cited in this paper were located from exhaustive searches of the Master Settlement Agreement document sites. The search string (pagewood or moorabbin or granville or australia* or sydney or melbourne or brisbane or hobart or adelaide or perth or canberra or amatil or wills) has been used throughout the project to gather documents relating to the Australian market. From the documents thus retrieved, all related to the issue of pesticides and additives were then reviewed. A full description of our search strategy can be found at http://tobacco.health.usyd.edu.au/site/gateway/ docs/research.htm\#search.

\section{RESULTS}

Part 1: pesticides

Tobacco is a crop that is attacked by a large variety of moulds, insects, and viruses from seedbed to storage in warehouses after manufacture. Those growing and manufacturing tobacco use various chemical agents to try and control these

Abbreviations: ASH, Action on Smoking and Health; BAT, British American Tobacco; DDT, dichlorodiphenyltrichloro-ethane; DTC, dithiocarbamate; $\mathrm{HCH}$, hexachlorocyclohexane; $\mathrm{MH}-30$, maleic hydrazide; NHMRC, National Health and Medical Research Council; PM, Philip Morris; TIA, Tobacco Institute of Australia 
problems, as well as experimenting with genetically modified tobacco varieties that might be more resistant to them. A wide range of pesticides (fungicides, insecticides, desuckering agents) are used on tobacco crops. In 1981, there were 52 different pesticides registered for use on tobacco in Victoria and Queensland, including seven organochlorines such as DDT (dichlorodiphenyltrichloro-ethane), deildrin, and aldrin, preparations which had been banned in many countries since the mid 1970s. Data on pesticide usage is not available for Australia, but in 1997 in the USA, 12235 tonnes were used on tobacco crops. ${ }^{8}$ Pesticide residue can remain on tobacco leaf after harvest and processing into its manufactured forms. When tobacco is smoked, these residues along with the tobacco and other additives are burnt, and the resultant smoky mixture inhaled by active and passive smokers is known as pyrolysis products. Burning at the temperatures generated in a lighted cigarette degrades but does not destroy chemicals in tobacco. A study to determine the chlorinated pesticide residue levels in mainstream smoke found that the "rate of transfer of pesticides from tobacco into smoke averaged about 12\%" of that in the tobacco before combustion. ${ }^{9}$ Other studies have reported that DDT, its derivatives, and pyrolysis products transfer into mainstream smoke at up to $20 \%$ of the residue in the unsmoked tobacco. ${ }^{1011}$

Pyrolysed pesticide residue is thus inhaled by smokers and may be one source of pesticide in the body, with several studies finding positive associations between smoking and levels of residue in breast milk. ${ }^{12-14}$ A 1973 study comparing samples of breast milk from women in Brisbane and Queensland's tobacco growing centre, Mareeba, found the Mareeba women had DDT at 16.9 parts per million (ppm) in their lactate compared to $8.6 \mathrm{ppm}$ among the Brisbane women. The National Health and Medical Research Council's (NHMRC) tolerance level was 1.25 ppm, some 13.5 times lower than the Mareeba levels. ${ }^{15}$ The study did not examine smoking in the women, so the much higher rates in the Mareeba women may have reflected exposure to DDT spray drift as well as smoking and exposure from other sources.

\section{Early government concern}

In October 1981, the NHMRC noted "that certain pesticide residues in Australian manufactured cigarettes were at levels appreciably higher than those in overseas brands... pesticide residues in tobacco were likely to increase the known adverse effects of inhaling tobacco smoke. Mean levels of dieldrin and DDT residues in particular had been determined at $0.09 \mathrm{ppm}$ and $7.3 \mathrm{ppm}$ respectively which, because of the amount absorbed from the smoke constituted cause for concern. Significant proportions of the tolerable daily intakes of these chemicals were likely to be attributable to this source in smokers. Council directed its Pesticides and Agricultural Chemicals Committee to undertake a scientific investigation into the levels of potentially harmful residues in cigarettes."16 No such investigation was ever conducted.

A background document prepared by the Department of Health 1981 showed that these "appreciably higher" levels were something of an understatement. The average level of DDT in Australian cigarettes sampled was 43 times higher than samples of UK and US brands. Dieldrin in Australian brands was 30 times higher, ${ }^{17}$ although as will be seen, such levels were eclipsed dramatically by levels found in Philip Morris' (PM) own testing.

Although the Department of Primary Industry suggested in 1985 that appropriate upper limits for agricultural chemical content in tobacco be set, this has never occurred, ${ }^{18}$ with government policy today stating: "As a matter of policy MRLs [maximum residue limits] are not set for residues in tobacco or in agricultural commodities used primarily for fibre production....as these are not food commodities"19 despite being taken into the body.

\section{Concern and testing within the industry}

Industry documents reveal global concern in the industry about pesticide residue. The potential for this issue to leak out to consumers via tobacco control activists caused the industry to engage in high security operations, as evidenced in a 1977 exchange between PM USA and its European office. Robert Seligman (vice president, research \& development, PM Incorporated, 1975-1980) wrote to Dr Max Hausermann from PM Europe. It had been previously suggested that tobacco samples be sent to Europe for pesticide testing by INBIFO, an industry laboratory. Seligman was concerned that "This suggested procedure is in direct conflict with our communications from the New York Office. We have gone to great pains to eliminate any written contact with INBIFO, and I would like to maintain this structure. Therefore, I am advising Jerry Osmalov to continue sending samples to Neuchatel for transshipment to INBIFO. If this procedure is unacceptable to you, perhaps we should consider a 'dummy' mailing address in Kóln for the receipt of samples.... I'll leave it to you to decide what route to follow" ${ }^{20}$

Similarly, when polyurethane was found in Australian tobacco in 1985, Seligman wrote to PM's Bill Webb in Australia advising that in the USA "the tobacco industry's position is to keep a low profile" on contaminants in tobacco and to try "to get 'the word' out to the grower to keep foreign material (including polyurethane materials) out of the tobacco... without arousing a public outcry from the antitobacco people". ${ }^{21}$ Polyurethane material was mainly used in curing barn insulation and "installed by small 'fly-by-night" contractors who go from farmer to farmer doing patchwork" [in barns.$^{21}$

\section{"Extremely" high levels}

In Australia, documents show evidence for industry concern about very high pesticide residue from 1972 until at least 1994 via tests undertaken in Switzerland for PM Australia. A 1972 report comparing chlorinated pesticide residue in Australian cigarettes with those from Finland found DDT in Australian brands ranging from 18.8-53.2 ppm while Finnish brands ranged from 3.6-7.5 ppm. ${ }^{22}{ }^{23}$ However, in 1978 a report noted "Extremely high pesticide residue levels have been found in all samples submitted by PM-Australia, e.g. DDT group: $>300 \mathrm{ppm}$; HCH-group* up to $100 \mathrm{ppm}$; Dieldrin: up to $22 \mathrm{ppm}^{\prime \prime} .{ }^{24}$ These levels could be considered almost astronomical against the $7.5 \mathrm{ppm}$ maximum standard for DDT that had been recommended in a 1976 report of the Commission of the European Communities ${ }^{25}$ and adopted by the German government.

In September 1983, maleic hydrazide residues on six Australian flue cured samples ranged from 82-119.2 ppm. ${ }^{26}$ PM Switzerland advised that the "proposed level for maleic hydrazide residues given by the German legislation is 80.0 ppm". ${ }^{26}$ In July 1984, 33/59 Australian tobacco samples had "high residue levels" of HCH (1.29-9.70 ppm) where the maximum permissible amount was $1 \mathrm{ppm}$ and for the DDT group in one sample (63.2 ppm where the maximum level was $10 \mathrm{ppm}$ ); dithiocarbamates in two samples (71 and $75.12 \mathrm{ppm}$ where the maximum recommended amount was $50 \mathrm{ppm}$ ); and for maleic hydrazide in two samples (85.2-124.9 ppm where the maximum recommended amount was $80 \mathrm{ppm}){ }^{27}$

*Hexachlorocyclohexanes $(\mathrm{HCH})$ are a group of manufactured chemicals that do not occur naturally in the environment. Lindane (gamma-HCH) is the most common form and was used on fruit, vegetable, tobacco, and forest crops. 
A report of a meeting of PM's pesticide subgroup from May 1985 noted: "samples out of a substantial quantity of Australian tobacco, intended for cigarette production, had been tested for residues. Dichloram residues were found up to an unusual high amount. ...The Upjohn Company confirmed that they had sold substantial quantities of Dichloram to Australia for tobacco stock protection." 28

In 1988, maleic hydrazide (MH-30) and dithiocarbamate (DTC) residues were found in various amounts in nearly all samples, with 11/38 samples having levels that exceeded the German tolerance levels. ${ }^{29}$ DDT and endrin were found in two samples. $^{29}$ Analysis reports in 1988-89 found similar results. $^{30-32}$ A further report in September 1989 found that $\mathrm{MH}-30$ exceeded the maximum $80 \mathrm{ppm}$ value in five samples (range $82-122 \mathrm{ppm}$ ); DTC (50 ppm maximum) in three samples (range 58.9-75.9 ppm); and dieldrin (0.1 ppm in USA) in three samples (range 2.5-5.9 ppm). ${ }^{33}$ This latter excess-5900\% higher than the maximum permissible level of dieldrin allowed in the USA in the case of one samplewas passed to PM without comment.

In 1991, 1992, and 1993, several reports showed that Australian samples had maleic hydrazide and dichloran residue over the German limits. ${ }^{34-37}$ Analyses from $1993^{38}$ found DDT above the maximum permissible residue limit for the USA and in 1994, 62/68 samples were over the recommended limits for dichloran. ${ }^{39}$ Significant DDT levels were found in 14 samples. $^{39}$

In summary, Australian use of organochlorines such as DDT began to decrease dramatically from the mid 1970s. By 1985 "virtually every one of the pest/crop/chemical combinations in agricultural [organochlorine] applications had been deregistered". ${ }^{40}$ The last DDT product approved for use on tobacco was deregistered in 1986 (table 1). With two years allowed for stock to be used up, DDT has thus not officially been used on tobacco in Australia since July 1988, yet was being found in Australian tobacco samples as late as 1994.

By 1997 RJ Reynolds reported: "There are no established limits for [pesticide use on] tobacco in Australia." ${ }^{\prime 41}$

Some 20 years after PM began shipping tobacco samples to Switzerland for testing, DDT was still being found at "significant" levels over the recommended limits. Australian consumers were told nothing of this throughout this period. There is nothing in the documents to indicate whether PM acted on the information it received and withheld the tobacco high in pesticide residue from its manufacturing process or whether it was used regardless. Given the industry's track record on denial of the health consequences of tobacco use per se, it would be entirely uncharacteristic for it to have withdrawn the tobacco in question, particularly as the contamination appeared to be so widespread. There were no industry press releases, no announcements of product recalls, no moves to advise or warn smokers on packs about these levels, and no records located about efforts to reform the farming practices of their suppliers.

This inactivity contrasts with a national recall of all PM's (Kraft) peanut butter in June 1996, when 50 cases of salmonella poisoning occurred "even though results to date

Table 1 DDT products registered for use on tobacco in Australia

\begin{tabular}{lll}
\hline Name & Dated cancelled & Date archived \\
\hline Shell DDT insecticide & 25 July 1983 & 25 July 1985 \\
NuFarm Toxipest & 1 July 1986 & 1 July 1988 \\
ICI Rulene & 22 July 1983 & 22 July 1985 \\
\hline
\end{tabular}

Source: Personal communication, National Registration Authority for Agricultural and Veterinary Chemicals, 3 September 2002. suggested that Kraft products had not been affected". ${ }^{42}$ Here, even the possibility of acute poisoning in its customers saw a PM national product recall, yet the "extremely high" DDT contamination of its tobacco samples submitted resulted in no product recall or warnings.

For the government's part, the advice it received from the NHMRC in $1981^{16}$ and again in 1985 from the Department of Primary Industry, appears to have been entirely ignored. Prompted to comment by advocacy from tobacco control groups, Australian Health Minister, Peter Staples, was reported as saying that smoking was "inherently dangerous and the significance of pesticide contamination was questionable". He said by placing emphasis on possible pesticide contamination, people might get the impression that smoking uncontaminated tobacco was safe. He said testing tobacco for pesticides gave the impression tobacco was like a food. "Tobacco cannot be likened in any way to a food ... Tobacco is a dangerous substance regardless of the levels of any additional substances." ${ }^{\prime 3}$

Today, cigarettes sold in Australia are made up of both local and imported leaf. With six (China, Zimbabwe, Brazil, Malawi, Cuba, and India) ${ }^{44}$ out of the top 10 countries of origin for tobacco imports into Australia being less developed nations where standards of agricultural regulation can be poor, Australian consumers can have little confidence in things being very different. If the Australian industry is still testing for pesticide residue in local and imported leaf, it is not releasing this information to consumers.

In the USA, a similar situation prevails. A 2003 US General Accounting Office report concluded: "While historically EPA [Environmental Protection Agency] has required pesticide manufacturers to provide data on the residues remaining on tobacco, its assessments of the health effects associated with exposure to the residues were not identified in risk assessment documents and generally were not quantified." ${ }^{8}$

\section{Part 2: additives}

Efforts to have consumers informed about pesticide residue were soon followed by advocacy to require the industry to reveal additives being used in Australian cigarettes and tobacco. The local industry appeared unprepared for this and even ill informed about the ingredients used in the products it was selling, as revealed in a memo reporting on calls made to PM USA regarding press coverage on this issue in 1981: "After some interrogation by press personnel here, it had become apparent that there was no regulatory mechanism for additives in Australia. On the assumption that there will be further press questions during 1981, the Tobacco Institute asked the Australian manufacturers what statement or statements could be made to press representatives if future questions arose. Wills had indicated to the Institute that all additives in their Australian products were within [UK] Hunter Committee† list." ${ }^{45}$

The memo reports a series of questions and answers put to Philip Morris USA during the calls. For example:

"Q: Does a formal regulatory procedure exist in the U.S. for manufacturers to gain approval for additives?

A: No. P.M.U.S. does comply with the F.D.A. list of food additives, but this does not cover any possible chemical change in the burning process." 45

The memo concluded: "Following these two calls, plus the fact that similar discussions are taking place with the U.S. Institute, it would appear to be in our interests to delay the formulation of any final statement despite the risk of having to offer a 'no comment' type answer to any premature press enquiry. ${ }^{\prime \prime 4}$

†The Independent Scientific Committee on Smoking and Health of the U.K 
PM USA followed this up explaining: “As I am sure you are aware, the subject of additives is a difficult one to handle, particularly with regard to inquiries from the media. ${ }^{\prime 46} \mathrm{PM}^{\prime} \mathrm{s}$ position in 1981 was that "... we are not prepared at this time to agree voluntarily to disclose additives used in cigarettes unless we are satisfied with the basis upon which the government will consider and evaluate additives" ${ }^{\prime 46}$ (emphasis in original).

In the USA, PM officials had met with their British American Tobacco Company (BAT) counterparts in the UK and reported back about BAT's "Guidance Panels on Additives and Materials". ${ }^{47}$ This document points to the acute sensitivity of the additive issue within the industry. BAT's panel proceeded with utmost caution and "will never make a claim of safety or of danger for an additive or a suspect material" and "will only respond to a specific question which is posed to them" by BAT staff. BAT Australia apparently undertook their own evaluation of additives with BAT UK reportedly being "not sure whether they have a system as formalized as the one described above" ${ }^{\prime 4}$

In the mid 1980s, PM distributed "a public relations response" on additives prepared by its lawyers, Covington \& Burling, to executives in several nations ${ }^{48}$ and in 1988 prepared a frequently asked questions sheet on additives ${ }^{49}$ apparently produced by the Canadian industry where the "issue raised its ugly head". ${ }^{50}$ This was distributed among the company following a report released by the UK Hunter Committee. The core message points were that additives used in PM tobacco had all been approved by the Hunter Committee or the German government; that they were entirely benign and no different to those used in foods; that while the food industry was obliged by law to reveal additives in foodstuffs, tobacco was different because "a similar approach would, in the tobacco industry, threaten the competitive position of the companies". ${ }^{49}$ The FAQ anticipated questions that "most of the additives... have never been subjected to any tests" and suggested the reply "The Hunter Committee only approved additives about which, on the basis of long term usage, no evidence existed of danger to health" ${ }^{49}$ This answer avoided addressing whether additives had indeed been subject to any safety testing and acknowledgement that the Hunter Committee's considerations were based on the safety of the additives when used in food, and not on studies of inhaled additive pyrolysis products.

Following the release by the US Department of Health of a list of additives used in the USA, in December 1988 PM Australia produced its own Q\&A sheet. ${ }^{51}$ Some of the more interesting model answers included:

"Q: Ammonia is on the list, do you use this ingredient?

A: Well, ammonia is naturally present in tobacco; it is an inherent agronomic ingredient in the tobacco leaf so there is nothing unusual about its presence." ${ }^{\prime 51}$

This was an extraordinarily deceptive and evasive answer, as PM had long engaged in the practice of adding ammonia to its cigarettes. ${ }^{52-56}$ Ammonia added to commercially made cigarettes can boost the bioavailability of nicotine up to 100 times-in short, making it more addictive. The process of increasing the impact of nicotine by adding ammonia is called "free-basing", which is similar to the chemical process used to heighten the effects of cocaine via crack cocaine. Like cocaine, nicotine exists in two forms-acid and base. When ammonia is added, the nicotine converts from acid to base form. The base form can vaporise more easily from the smoke particles into the gas phase, enabling it to deposit directly on the lung tissue and immediately diffuse throughout the body. ${ }^{57}$

Another question revealed a strategy of excusing nondisclosure behind a broad appeal to government regulation:
"Q: Does this list include pesticides or insecticides?

A: No it does not and before you ask your next question, you should be aware that before any insecticide or pesticide can be used in this country, it must have Government certification for its use and its rate of use." ${ }^{\prime 51}$

A 1990 Q\&A sheet on additives and smoke constituents circulated around PM officials introduced two novel considerations into the debate. ${ }^{58}$ The answer proposed for the question "Are these constituents dangerous?" ventured that some so-called carcinogens in tobacco smoke might actually have the opposite effect and prevent cancer: "It should be noted...that some compounds that are carcinogenic in test animals, when applied in isolation, have been found to be anti-carcinogenic when applied in combination with each other. It has long been known that certain smoke constituents act as anti-carcinogens in test animals...many constituents of cigarette smoke have been found to be anticarcinogenic when applied with true carcinogens in test animals." ${ }^{58}$

This document also justified non-disclosure of ingredients via the industry's concern that such disclosure might be "counterproductive": "Warning labels have proliferated on numerous consumer products... This has led a number of communications experts to voice concern about 'warning overload'-that is a tendency on the part of consumers to begin to ignore warning labels entirely....if presented with too much label information, many consumers will misunderstand the warnings. In fact, one study found that consumers thought products with rather elaborate warning labels were safer than those without them." ${ }^{58}$ This was a very disingenuous argument: if large ingredient warning labels convinced smokers that tobacco products were safer, or to ignore the content of the warnings, this would clearly be in the industry's interests-yet they were being resisted.

The document noted: "...typical industry-wide usage of individual flavor components is under 10 pounds a year. This is in contrast to the over 850 million pounds of tobacco employed in cigarettes sold in the United States each year." 58 If we assume that 500 such individual flavour components were in active use across all brands, then this stated ratio of additives to tobacco $(1: 170000)$ may be contrasted with the ratios revealed in disclosures made to the New Zealand government in 1991 (range $0.2-33.4 \%$ additives) (table 2). A 1994 PM analysis of all brands on the Australian market includes information on the proportion of total cigarette weight taken up by "non-tobacco components". For example, Freedom $1 \mathrm{mg}$ weighed $753 \mathrm{mg}$ with non-tobacco components weighing $217 \mathrm{mg}$ and tobacco weighing $536 \mathrm{mg}$ of total weight. The filter weighed $132 \mathrm{mg}$, meaning that $15.8 \%$ of the "tobacco" was paper and additives. ${ }^{59}$

We do not know if the industry publicly used this wilful trivialisation of the levels of additives in tobacco, but this document reveals that it rehearsed an intention to do so.

\section{Health groups lobby for disclosure}

In July 1990, the Australian Consumers' Association and Action on Smoking and Health (ASH) published open letters in Melbourne newspapers titled "What's your poison?"'60 and "Chemical Hazard" ${ }^{61}$ calling on the tobacco industry to reveal "what chemicals are routinely added to Australian cigarettes? What product safety criteria do you use before deciding to add these chemicals? Have you tested the safety of prolonged exposure to these chemicals on human subjects?" The campaign generated significant debate, with an editorial in the Brisbane Sun being typical: "Under Australian law, tobacco manufacturers do not have to reveal the ingredients in cigarettes. How absurd. While we are able to study the ingredients in our food, we are rendered blind to a host of toxic nasties in a product sold in every corner shop. It is time 
Table 2 Ratio of additives to tobacco in Wills and Rothmans tobacco products, New Zealand $1991^{70}$

\begin{tabular}{lccc}
\hline & $\begin{array}{l}\text { Tobacco weight } \\
\text { (tonnes) }\end{array}$ & $\begin{array}{l}\text { Weight of additives } \\
\text { in total (tonnes) }\end{array}$ & $\begin{array}{l}\text { Percentage of } \\
\text { additives by weight }\end{array}$ \\
\hline Wills cigarettes & 879.219 & 1.803 & 0.2 \\
Wills cigarette tobacco & 366.036 & 82.456 & 22.5 \\
Wills pipe tobacco & 6.695 & 2.227 & 33.4 \\
Rothmans cigarettes & 2271.04 & 10.184 & 0.4 \\
Rothmans cigarette tobacco & 280.495 & 30.108 & 10.7 \\
Rothmans pipe tobacco & 21.862 & 3.565 & 16.3 \\
\hline
\end{tabular}

manufacturers were forced to include a list of all ingredients on cigarette packets. Perhaps then smokers could make an educated decision." 62

The national TV consumer program The Investigators covered the issue twice, ${ }^{63}$ precipitating an announcement by the NSW Minister for Health that he had directed his department to "examine the feasibility of tobacco manufacturers being compelled to list the contents of their products on packets... Such standards already apply to almost all packaged food preparations and beverages. Under these standards consumers are able to make decisions for themselves about what they eat and drink." ${ }^{\prime 64}$

PM became concerned that this momentum meant "...we are seriously being confronted with additive, ingredient and/ or constituent labelling in this country". ${ }^{65}$ Above all, their concern was how to prevent this momentum leading to pack labelling of additives: "...it is my intention that the Industry here in Australia establishes a position and a position paper on what we can say to...the relevant Health Ministers, N.H. \& M.R.C., health bureaucrats and other promoters of this issue to prevent packet labelling." ${ }^{65}$ The four companies prepared a joint position "Cigarette ingredients: Why ingredients at all?". ${ }^{66} 67$

\section{New Zealand developments}

In 1991, the New Zealand Minister for Health had been requesting disclosure of individual additives actually used in NZ cigarettes from the Tobacco Institute of New Zealand. BAT UK's Sharon Boyse wrote that BAT would not provide the information if it would be accessible to consumers and that in any case, BAT would be withholding information on "additives that we already use plus 'scramblers"': "...we will only provide this information should we be assured that it will not be available under your Freedom of Information Act... I must stress the importance of keeping us informed at all stages of your discussions because this is an extremely sensitive issue that...has implications outside New Zealand. I must also stress that a list of additives currently used by product class is the only acceptable alternative to provision of the combined regulatory list and that we cannot provide anything in between ie additives that we already use plus 'scramblers'." 68 "Scramblers" were bogus ingredients added to disclosure lists in efforts to set false trails for competitors and "protect the proprietary aspects of the formula". ${ }^{69}$

\section{Media frenzy}

In 1994, the issue flared up again in Australia when two documents obtained via New Zealand's freedom of information laws unleashed a major news event in March. The New Zealand Tobacco Control Act (1990) required tobacco companies to supply the Health Department with an annual list of all additives that they might be using in their tobacco products. The list was not released to the public and does not specify which additives are selected from the list for actual use. Two identical lists of 2168 additives and chemicals approved for use by the industry in Europe were submitted by the two main companies operating in New Zealand, W.D. \& H.O. Wills (New Zealand) Limited (a BAT subsidiary) and Rothmans of Pall Mall (New Zealand) Limited for the year 1991.

The submissions showed the weights of additives (table 2), with pipe and roll-your-own tobacco being heavily adulterated, putting an end to the myth espoused by many roll-yourown smokers that their tobacco is "more natural".

The information was released by the NSW Cancer Council at a press conference. Over the next two days, the story was covered extensively in the Australian media.

The huge media reception reflected several news frames or values that made it highly compelling to the Australian media. ${ }^{70}$ However, no changes to disclosure resulted from the publicity.

\section{The "Coca Cola defence" of non-disclosure}

An International Ingredients Regulatory group was formed in 1993 with eight companies under PM leadership. Its objectives were to "protect business interests, protect trade secrets, unified industry position...". ${ }^{71}$ The group developed a "...worldwide ingredients list for use in addressing regulatory requirements for ingredients disclosure". ${ }^{72}$ A list of 599 additives used by USA companies was submitted as a list that PM Australia also uses, although those actually used from the list were not specified. Each entry listed other foodstuffs in which each additive was used-part of PM's "normalisation" strategy. ${ }^{73}$

In 1995, in responding to an Australian Senate enquiry, the Tobacco Institute of Australia (TIA) noted that "...we consider that there is no demonstrated consumer demand that such information be disclosed". ${ }^{74}$ According to the TIA, smokers were not asking for information on additives they did not know were being used. Quoting from the PM submission to the Senate, the TIA wrote: "There are trade formulas, much like the Coca-Cola formula, and putting them on the side of our pack would be giving our competitors a distinct commercial disadvantage. We like to think our cigarettes are superior to theirs, and I'm sure they like to think the same about their own products. But there are commercial issues here about putting formulas and ingredients on the side of packs." ${ }^{74}$

The Senate inquiry released its report in 1995, together with a minority report opposing many of the recommendations. There were two recommendations regarding labelling:

- that a list of the ingredients added to tobacco products be provided annually to the Commonwealth government, on a confidential basis, by those tobacco companies whose products are sold in Australia

- that a list of the ingredients in tobacco products, and their effects, be distributed (in an appropriate form) with all tobacco products sold in Australia. ${ }^{75}$ 
PM's Eric Windholz wrote to his colleagues that the "recommendations will not automatically be translated into legislation... It is now a question of politics as to whether all or some or none of the recommendations are implemented. ${ }^{\prime 76}$ The industry's political lobbying apparently succeeded, with RJR noting “...the Australian government, by law, had a period of 90 days to act on the recommendations, but allowed this deadline to pass with no action... the pursuit/ enactment of these recommendations is not a top priority of the new Australian government.,"77

In 1999, the British Columbian government in Canada became the first government in the world to require all brands on sale in Canada to disclose via a website brand-bybrand additive lists. ${ }^{78}$ This action set a precedent that was seized by local Australian advocates and quickly gained favour with the federal health minister, Michael Wooldridge.

PM Australia's Eric Windholz reported back to colleagues following discussions between the industry and the Department of Health in November 1999, emphasising industry strategy to pre-empt government legislation by voluntarily declaring limited information that excluded pesticide residue, and avoided pack additive listing by placing limited information on websites:

"The Government is committed to pursuing disclosure as
soon as possible... The Government stated that it intends
to disseminate ingredient information to the public (but has
not decided how), and that it could not prevent the
companies from doing so simultaneously ... the Minister's
original request referred to British Columbia style dis-
closure. [A bureaucrat] then asked whether the tobacco
companies accept the four principles for disclosure set out
in the agenda. Brady [from BAT] took issue with the
reference to a consumer's right to know. He queried
whether there is a consumer demand for the information;
whether it is useful; will consumers use it? ... Windholz
explained that the Protocol assumes a definition that is a
combination of 'ingredient' and 'additive', provided it is
limited to substances intentionally or knowingly added by
manufacturers and does not extend to crop protection
agents [i.e. pesticides]. ...Brady suggested that in the
absence of demonstrated demand for the information, the
information could be made available upon request (e.g.
via the Internet) as opposed to actively disseminating it."

2000 voluntary agreement signed: secrets continue A voluntary disclosure agreement between the companies and the Australian government was signed on 20 December $2000 .^{80}$ This agreement provided for brand-by-brand disclosure of ingredients by descending order of weight. However, significant exclusions were "flavourings that give each brand its unique characteristics" and "processing aids and preservatives that are not significantly present and do not functionally affect the finished product". Nowhere were any of terms like "significantly present" or "functionally affect" defined.

Today, every brand of cigarette sold in Australia marketed by BAT and Philip Morris is described as including unspecified "processing aids". ${ }^{82}$ Effectively then, the voluntary agreement revealed nothing the industry wanted to remain secret, and so Australian consumers continue to be unable to make informed choices about the brands they select. An internal BAT 1994 document noted that "BAT is happy to disclose information on ingredients so long as brand recipies [sic] are protected". ${ }^{83}$

Among the internal documents are occasional glimpses of the sort of additives the industry does not wish to reveal to the public. In 1981 PM noted that "Marlboro concentrate, Alpine exotic, P.M. flavour, BD-1 additive..." were being imported into Australia. ${ }^{84}$ If these are still being used, none appear in the lists released in 2000. Similarly, a 1993 letter from RJR USA to Rothmans Australia requested “...further information regarding the mixing formulas and the actual application rates for the top flavors being used on Blends 9 and 13 ...the amounts of these materials which are added to the Quest DC05162, IFF GA502544 and the ITC-14 concentrates to produce the final top flavor (which is applied to the tobacco)..." ${ }^{85}$ None of the Australian industry websites list any of these ingredients.

Indeed, Australian companies were themselves kept ignorant of what it was they were adding to the local blends. For example, in 1984 WD\&HO Wills Australia wrote to Brown and Williamson about "ingredient MGE-7". ${ }^{86}$ Wills was introducing a "total Quality Assurance...involv[ing] routine inspections of incoming materials. Because of the confidentiality we appreciate you would not be able to provide us with full specifications for Ingredient MGE-7 but whatever specifications you are able to pass on to us, preferably with corresponding tolerance, would be appreciated. One detail of particular use in facilitating our test procedures would be the molecular weight of the product.." ${ }^{\prime 86}$

Despite the companies continually insisting that the additives were safe, some documents suggest otherwise. In 1993, Rothmans Australia wrote to RJR International requesting a product information sheet for "ITC 14 flavour used to manufacture Now cigarettes", an ultra "light" brand which Rothmans were distributing in Australia. ${ }^{87}$ The Material Safety Data Sheets provided stated: "The composition of this product is considered to be a trade secret by R.J. Reynolds Tobacco Company" and that "No Federal OSHA exposure standard or ACGIH TLV has been established for this material." $\ddagger$ Nonetheless, Reynolds were aware that "Ingestion during pregnancy resulted in birth defects and reproductive effects in laboratory animals". ${ }^{87}$

Perhaps no documents yet discovered are so disturbing as a report written in 1977 by Dr Sydney Green, BAT's Senior Scientist for Research and Development in the UK. ${ }^{88}$ In a memo on scientific developments Green wrote: "A way-out development is that of compounds (such as etorphine) which are 10,000 times as effective as analgesics as morphine and which are very addictive. It is theoretically possible (if politically unthinkable) to add analytically undetectable quantities of such materials to cigarettes to create brand allegiance. But this thought may suggest the possibility of such compounds occuring [sic] naturally." 89 Etorphine, known among veterinarians as elephant juice because a small drop will kill an elephant, was used in race horse doping because a very small dose can produce hyperexcitability in horses. Further references to this development in the documents has not been found, but in view of the gargantuan degree of document destruction known to have occurred in the industry ("I should advise you that I authorized the destruction of close to 1 million individual pages in my seven years at the TDC [Tobacco Documentation Centre]..."), ${ }^{90}$ clues such those found in Green's memo take on special significance.

\section{Freon}

Finally, the tobacco industry in Australia also sought to cover up its contribution to the environmental health problem of ozone depletion. Until November 1999, Australian cigarettes were taxed on a per weight basis. This provided the industry with an incentive to reduce the weight of Australian

$\ddagger$ American Conference of Government Industrial Hygienists threshold limit value. 
cigarettes in the quest to keep retail price as low as possible. From at least 1970, tobacco used in some Australian cigarettes sold by Wills was treated by a process known as G13, whereby freon was used to expand the tobacco when heated and thus requiring less tobacco to fill a cigarette. Freon, a chlorofluorocarbon (CAS 75-69-4) was most popularly used as a coolant in air conditioning and refrigeration and as an aerosol propellant until it was discovered that it was an ozone depleting substance in the 1970s. Adding 10\% of G13 expanded tobacco could result in a $5.5 \%$ reduction in total tobacco weight. ${ }^{91}$

BAT was deeply concerned that continuing use of freon could cause additional backlash against the industry ("If controversy develops, it would be undesirable for the tobacco industry or for B.A.T. to be seen among the polluters" $).{ }^{92} \mathrm{WD}$ $\&$ HO Wills "increased their effort and expense to control the Freon level" and in March 1977 BAT agreed that "the installation of any new G.13 plant should cease at once", noting "Bearing in mind that the other uses of Freon in the consumer arena have been either restricted or voluntarily abandoned. The tobacco industry's use would seem to carry a greater risk of public criticism" ${ }^{93}$ Nonetheless BAT continued to use freon in its Singapore plant until $1990 .{ }^{94}$

In 1978, Haywood C Smith of the Arjay Equipment Corporation (Winston-Salem) wrote to the Director of Manufacture, WD \& HO Wills (Australia) Ltd concerning the BAT G13 facility in Australia. Wills had been concerned about Philip Morris threatening to reveal that Wills was selling cigarettes processed with G13: "Your concern about the possibility of PM blowing the whistle on G-13 in Australia has caused me further thought, particularly the aspect of their declining market share prompting such a dirty trick... In the past, we have taken comfort in (a) PM not having pulled such a trick for the nine years of G-13 usage and (b) the probability that such a stunt would damage the industry as a whole and ultimately themselves. Doing stunts to gain market share may not be strange to PM but doing so on the basis of a highly technical point would be a very shortsighted move which I believe the people in PM New York recognize." ${ }^{\prime 95}$ Smith then suggested that the Australian health department might provide surreptitious approval to use G13: "Alternatively, Wills or Wills/Rothmans together may wish to consider an informal approach to the proper person in the government agency responsible for health matters. The objective of the approach would be to obtain an unofficial blessing on the use of G-13-even if temporary or with some qualification attached to future research or the like." ${ }^{195}$ As with pesticide residue and additives, yet again, Australian consumers were told nothing about an issue the companies well understood was likely to be of high public interest.

\section{CONCLUSION}

Australian smokers, like their international counterparts with the recent exception of Canada, have been continually kept in ignorance about the constituents of tobacco products. Tobacco in Australia remains an unregulated product. As an "ingested" product causing major health consequences, it is produced and marketed in a regulatory "no-man's land", being not subject to pharmaceutical, food and beverage, or poisons regulatory frameworks. There is nothing preventing Australian tobacco manufacturers adding almost any ingredient they choose.§ They do not have to register such ingredients, indicate the purpose for their use, the amount used, nor provide any consumer safety information about the consequences of inhaling their pyrolysis products. The "Coca

§They would not be able to add restricted substances such as morphine derivates, although this was once considered by a senior PM official, as a potential solution to suppressing smokers' coughs. ${ }^{96}$

\section{What this paper adds}

The international tobacco industry has long been highly sensitive to consumer reaction to the contamination of tobacco leaf by pesticides and over how to safeguard proprietary information about its use of chemical additives for flavouring, moisture retention, and temperature control.

Australian tobacco leaf was often highly contaminated with organochlorine residue until at least the early 1990s. Consumers were told nothing about this. In the face of consumer advocacy for additive disclosure, the Australian industry agonised over how to reassure consumers about additive safety, while disclosing nothing about its additive practices. A 2000 voluntary agreement to disclose additives effectively allowed companies to disclose only non-sensitive ingredients and, by grouping secret ingredients under "processing aids", to continue to deny consumers full

Cola" defence-the notion that tobacco companies are entitled to retain chemical trade secrets and only release information they regard as insignificant to consumersinsults the very foundations of consumer sovereignty, particularly given tobacco's established record as an unhealthy product.

Historically, the Australian government's attitude to nondisclosure has been to argue "smoking itself is very unhealthy. We do not believe that further information about potential additional health problems arising from additives and pesticides is therefore warranted. Smokers are already risking much...further information would be simply "turning the temperature up a few degrees" in an already alarming communicative environment about tobacco's dangers." This argument is myopic, as given broad consumer concern for additives and pesticides, provision of such information may well precipitate cessation in many.

In 1990, the National Centre for Research into the Prevention of Drug Abuse and the Western Australian Health Department conducted a series of studies across Australia designed to explore what smokers knew about tobacco ingredients, pesticides, and additives. ${ }^{97}$ The report found that "levels of knowledge regarding the presence of pesticides and other chemicals in cigarettes were extremely low" with only one substance-arsenic_being named unprompted by more than $1 \%$ of those interviewed. Further, when asked hypothetical questions as to how a warning specifying "small quantities of arsenic, DDT, lead and asbestos" would affect their smoking behaviour, 61\% said they would cut down their smoking or quit; $86 \%$ of smokers said they would be "worried" by such a warning. ${ }^{97}$ The industry obtained this report, and its findings are consistent with the industry's decades long efforts described in this paper to prevent consumer awareness of pesticides and additives.

\section{ACKNOWLEDGEMENTS}

This research was funded by grants from the US National Institutes of Health (R01 CA87110-01A1) and the Australian National Health and Medical Research Council (153857).

\section{REFERENCES}

1 Teague C. Research planning memorandum on some thoughts on tobacco smoke flavors and mouth-feel: draft. R J Reynolds. Bates No. $511223585 /$ 3592. 12 Feb 1973. http://legacy.library.ucsf.edu/tid/vte53d00

2 Farone W. The manipulation and control of nicotine and tar in the design and manufacture of cigarettes: a scientific perspective: declaration to the Food and Drug Administration, Mar. 8, 1996. http://www.courttv.com/legaldocs/ business/tobacco/statements.html (Accessed 23 Oct 2002)

3 WD \& HO Wills (Australia) Ltd. WD \& HO Wills (Australia) Limited Research and Development Department quarterly report, August-October 1985. Brown 
\& Williamson. Bates No. 620787211/7229.1986. http:// legacy.library.ucsf.edu/tid/byu21 foo

4 Connolly G, Wayne G, Lymperis D, et al. How cigarette additives are used to mask environmental tobacco smoke. Tobacco Control 2000;9:283-91.

5 Gullotta F, Hayes C, Martin B. Raison d'etre. 8 Nov 1990. Philip Morris. Bates No. 2028813366/3368. http://legacy.library.ucsf.edu/tid/lkz74e00

6 Green S. Notes on group Research \& Development Conference, Sydney. March 1978. British-American Tobacco Company. 6 Apr 1978. Philip Morris. Bates No. 2050987449/7455. http://legacy.library.ucsf.edu/tid/ oac62e00

7 Webb W. Status of the Marlboro Development Programme. 12 Jul 1984 Philip Morris. Bates No. 2023265662/5664. http://legacy.library.ucsf.edu/ $\mathrm{tid} / \mathrm{gmr} 98 \mathrm{e} 00$

8 United States General Accounting Office. Pesticides on tobacco: federal activities to assess risks and monitor residues. (GAO-03-485). Washington DC: GAO, 2003. http://www.house.gov/reform/min/pdfs/pdf_inves/ pdf_tobacco_gao_pesticide_rep.pdf

9 Clapp W, Shelar G. The determination of chlorinated pesticides in mainstream smoke. 21 Jun 1972. R J Reynolds. Bates No. 500615633/5638. http:// legacy.library.ucsf.edu/tid/cdv69d00

10 Atallah $\mathrm{Y}$, Dorough $\mathrm{H}$. Insecticide residues in cigarette smoke: transfer and fate in rats. J Agric Food Chem 1975;23:64-71.

11 Bowery T, Gatterdam P, Guthrie F, et al. Fate of inhaled C14-TDE in rabbits. $J$ Agric Food Chem 1965; 13:356-9.

12 Vuori E, Tyllinen H, Kuitunen P, et al. The occurrence and origin of DDT in human milk. Acta Paediatr Scand 1977;66:761-5.

13 Bradt P, Herrenkohl R. DDT in human milk: what determines the levels? Sci Total Environ 1976;6:161-3.

14 Dillon J, Martin G, O'Brien H. Pesticide residues in human milk. Food Cosmet Toxicol 1981;19:437-42.

15 Miller G, Fox J. Chlorinated hydrocarbon pesticide residues in Queensland human milks. Med J Aust 1973:2:261-4.

16 National Health and Medical Research Council. Report of the ninety-second session, Canberra, October 1981. Canberra: AGPS, 1982:18

17 Department of Health. Pesticide residues in tobacco. Unpublished document prepared by the Commonwealth Department of Health for the National Health and Medical Research Council, 1981.

18 Standing Committee on Agriculture. Technical Committee on Agricultural Chemicals Protocol of requirements for chemicals used on tobacco. Canberra: Department of Primary Industry, 1985. (Document PB 479).

19 National Registration Authority for Agricultural and Veterinary Chemicals. MRL standard: maximum residue limits of agricultural and veterinary chemicals. Preface. National Registration Authority for Agricultural and Veterinary Chemicals. http://www.nra.gov.au/residues/mrl6.pdf (Accessed 23 Sep 2002

20 Seligman R. [Letter to $\operatorname{Dr}$ M. Hausermann]. Philip Morris. Bates No. 2046754686/4687. 31 Mar 1977. http://legacy.library.ucsf.edu/tid/ eeo65e00

21 Seligman R. Foreign materials in tobacco. 15 Feb 1985. Philip Morris. Bates No. 2000510121/0122. http://legacy.library.ucsf.edu/tid/hlw56e00

22 Philip Morris. Chlorinated pesticide residues in Australian cigarettes. Feb 1972. Bates No. 2000706359/6361. http://legacy.library.ucsf.edu/tid/ rvj35e00

23 Lowman F Pesticide residue-DDT 16 Feb 1972. Philip Morris. Bates No. 2000706358. http://legacy.library.ucsf.edu/tid/wvj35e00

24 Fink W, Moser F, Speck M. Agricultural chemicals, 25 January to 20 February 1978. Feb 1978. Philip Morris. Bates No. 2501185696/5697. http:// legacy.library.ucsf.edu/tid/fvm23e00

25 Commission of the European Communities. Pesticide residues in tobacco and tobacco products. Volume 1, Information on agriculture. Brussels: Commission of the European Communities, 1976:62.

26 Moser F. [Letter to T. Housepeters]. FTR Research and Development. 29 Sep 1983. Philip Morris. Bates No. 2501291620. http://legacy.library.ucsf.edu/ $\mathrm{tid} / \mathrm{csk} 29 \mathrm{e} 00$

27 Moser F. [Cigarette analysis results]. FTR Research and Development. $30 \mathrm{Jul}$ 1984. Philip Morris. Bates No. 2501291618/1619. http:// legacy.library.ucsf.edu/tid/ksk29e00

28 Wittekindt W. Meeting of the Subgroup Pesticide, May 8-9, 1985. Verband Der Cigarettenindustrie (VDC). May 1985. Philip Morris. Bates No. 2501297416/7418. http://legacy.library.ucsf.edu/tid/zpm32e00

29 Speck M. Pesticide residue analysis. FTR Research and Development. 10 Mar 1988. Philip Morris. Bates No. 2501297408/7409. http:// legacy.library.ucsf.edu/tid/vpm32e00

30 Speck M. Pesticide residue analysis. FTR Research and Development. 8 Jul 1988. Philip Morris. Bates No. 2501297346. http://legacy.library.ucsf.edu/ $\mathrm{tid} / \mathrm{lel} 29 \mathrm{e00}$

31 Speck M. Pesticide residue analysis. FTR Research and Development. 12 Aug 1988. Philip Morris. Bates No. 2501297329 . http://legacy.library.ucsf.edu/ $\mathrm{tid} / \mathrm{sel} 29 \mathrm{eO0}$

32 Amati D. Pesticide residue analysis. FTR Research and Development. 6 Mar 1989. Philip Morris. Bates No. 2501297071/7106. http:// legacy.library.ucsfedu/tid/zuk29e00

33 Amati D. Pesticide residue analysis. FTR Research and Development. 25 Sep 1989. Philip Morris. Bates No. 2501297238. http://legacy.library.ucsf.edu/ $\mathrm{tid} / \mathrm{ftk} 29 \mathrm{eO0}$

34 Haib J. Pesticide residue analyses of Australian samples. FTR Research and Development. 8 Jul 1991. Philip Morris. Bates No. 2501296456/6508. http://legacy. library.ucsf.edu/tid/hik29e00

35 Haib J. Pesticide residue analyses of Australian samples. FTR Research and Development. 5 Aug 1991. Philip Morris. Bates No. 2501296440/6455. http://legacy.library.ucsf.edu/tid/gik29e00
36 Haib J. Pesticide residue analyses of Australian samples. FTR Research and Development. 4 May 1992. Philip Morris. Bates No. 2501296225/6254. http://legacy.library.ucsf.edu/tid/wjk29e00

37 Haib J. Pesticide residue analyses of Australian samples. FTR Research and Development. 13 Sep 1993. Philip Morris. Bates No. 2501296848/6869. http://legacy.library.ucsf.edu/tid/qhk29e00

38 Haib J. DDT analyses. 2 Feb 1993. Philip Morris. Bates No. 2501301334 http://legacy.library.ucsf.edu/tid/bep32e00

39 Haib J. Pesticide residue analyses of Australian samples. FTR Research and Development. 10 Feb 1994. Philip Morris. Bates No. 2501301709/1711. http://legacy.library.ucsf.edu/tid/hgh29e00

40 Harrison S. Organochlorines in Australia. United Nations Environment Programme, Chemicals (UNEP Chemicals) 1997. Last updated: 12 Aug 2002. http://www.chem.unep.ch/pops/POPs_lnc/proceedings/bangkok/ HARRISON.html (Accessed 23 Sep 2002)

41 Summary of worldwide pesticide regulations within industrial \& environmental toxicology. 11 Feb 1997. R J Reynolds. Bates No. 517560025/0027. http://legacy.library.ucsf.edu/tid/jsf40d00

42 Delvecchio J. Peanut butter recall widened in health scare. Sydney Morning Herald 27 Jun 1996:3.

43 Pesticides in tobacco 'irrelevant to debate'. Gold Coast Bulletin 11 Jul 1990:49.

44 ABS International Trade Statistics. Tobacco and tobacco product imports for Australia, 2001-2002. VicHealth Centre for Tobacco Control. http:// www.vctc.org.au/tc-res/Imports_Tobacco_2001-2002.xls (Accessed 22 Oct 2002)

45 O'Brien J. Report on two phone calls to P.M. U.S. 12 Feb 1981. Philip Morris. Bates No. 2023084970/4972. http://legacy.library.ucsf.edu/tid/ lgo87e00

46 Resnik F. [Letter to D. Curlewis]. 31 Jul 1981. Philip Morris. Bates No. 2025042941/2943. http://legacy.library.ucsf.edu/tid/gmo04e00

47 Osdene T. B.A.T. guidance panels on additives and materials (your memo, May, 14, 1981). 15 May 1981. Philip Morris. Bates No. 1000123657/ 3659. http://legacy.library.ucsf.edu/tid/nnd02a00

48 Whist A. Cigarette ingredients. 4 Apr 1986. Philip Morris. Bates No. 2021583195/3196. http://legacy.library.ucsf.edu/tid/ouv58e00

49 Philip Morris. Possible questions and answers on additives. 6 Dec 1988. Philip Morris. Bates No. 2023034825/4829. http://legacy.library.ucsf.edu/tid/ $\mathrm{sdm} 58 \mathrm{e} 00$

50 VonMaerestetten C. Additives. 6 Dec 1988. Philip Morris. Bates No. 2504075065. http://legacy.library.ucsf.edu/tid/nok02a00

51 Francis P. Ingredients-Q \& A. 16 Dec 1988. Philip Morris. Bates No. 2504075061/5063. http://legacy.library.ucsf.edu/tid/uhi29e00

52 Wilson T. [Letter to Dr R.R. Johnson]. WD \& HO Wills (Australia) Ltd. 27 Jul 1989. Brown \& Williamson. Bates No. 620500327. http:// legacy.library.ucsf.edu/tid/lbh01f00

53 Driscoll D. Cigarettes constructed of treated Australian bright tobaccos. 14 Dec 1983. Philip Morris. Bates No. 2024761 107/1109. http:// legacy.library.ucsf.edu/tid/plv46e00

54 Harward C, Kuhn W, Parrish M, et al. Ammonia in cigarette smoke by TDL. Part II, Evaluation of tobacco products and Marlboro and Winston cigarettes (1752 cigarette smoke studies). 17 Apr 1984. Philip Morris. Bates No. 2023363541/3572. http://legacy.library.ucsf.edu/tid/bqi53e00

55 Murray R. Capital Appropriation Request Dry Ice Expanded Tobacco PlantPhilip Morris Limited (Australia). 10 Mar 1986. Philip Morris. Bates No. 2023270271. http://legacy.library.ucsf.edu/tid/htt24e00

56 William D. Australian cigarettes. 9 Sep 1994. Philip Morris. Bates No. 2050755286. http://legacy.library.ucsf.edu/tid/sul79e00

57 Pankow J, Mader B, Isabelle L, et al. Conversion of nicotine in tobacco smoke to its volatile and available free-base form through the action of gaseous ammonia. Environ Sci Technol 1997;31:2428-33.

58 Philip Morris. Questions and answers concerning tobacco constituents and ingredients. Philip Morris. Bates No. 2025372335/2352. 1990. http:// legacy.library.ucsf.edu/tid/huq95e00

59 Ruff R. Philip Morris Limited (Australia) C.I. report no. 84. Jun 1994. Philip Morris. Bates No. 2057967669/7753. http://legacy.library.ucsf.edu/tid/ vcp96e00

60 Quit Campaign. What's your poison? The Sun (Melbourne, Vic). 2 Jul 1990. Philip Morris. Bates No. 2500078772B. http://legacy.library.ucsf.edu/tid/ yzi19e00

61 Australian Consumers' Association, Action on Smoking and Health Chemical hazard: an open letter to the Australian tobacco industry. The Age 7 Apr 1990. Philip Morris. Bates No. 2025372328. http:// legacy.library.ucsf.edu/tid/muy83e00

62 Anon. Editorial. Sunday Sun 8 Jul 1990:44.

63 Croll Monitoring Australia. Chemical additives in cigarettes: transcript from The Investigators, ABC programme. 24 Jul 1990. Philip Morris. Bates No. 2024966336/6340. http://legacy.library.ucsf.edu/tid/ymk24e00

64 Collins P. Minister seeks advice on tougher labelling of cigarette packets. 24 Jul 1990. Philip Morris. Bates No. 2024966341. http:// legacy.library.ucsf.edu/tid/zmk24e00

65 Francis P. Ingredients. 27 Jul 1990. Philip Morris. Bates No. 2024966334/ 6335. http://legacy.library.ucsf.edu/tid/ivp46e00

66 Philip Morris. Cigarette ingredients - 'why ingredients at all?': draft summary positions. Sep 1990. Philip Morris. Bates No. 2025372357/2360. http:// legacy.library.ucsf.edu/tid/cuq95e00

67 Pimblett KD. Position papers ex TIA. 24 Sep 1990. R J Reynolds. Bates No. 507891 158/1 158. http://legacy.library.ucsf.edu/tid/ndi14d00

68 Boyse S. [Fax to Michael Thompson]. British-American Tobacco Company Ltd. 22 Feb 1991. Philip Morris. Bates No. 2023246498/6499. http:// legacy.library.ucsf.edu/tid/vgc58e00 
69 Sachs R, Rosenblatt N. Agreement of disclosure and confidentiality [between Lucia and B\&W]. 27 Jun 1983. Brown \& Williamson. Bates No. $511001203 /$ 1206. http://legacy.library.ucsf.edu/tid/big20fo0

70 Chapman S. New disclosures in additives from New Zealand. Tobacco Control 1994:3:206-7.

71 Philip Morris. Regulatory issues update. Jul 1993. Philip Morris. Bates No. 2021517232/7266. http://legacy.library.ucsf.edu/tid/zeg22d00

72 International Ingredients Group. International ingredients meeting, 3 May 1995, Duesseldorf, Germany. Lorillard. Bates No. 88026355/6359. Jul 1993. http://legacy.library.ucsf.edu/tid/hru20e00

73 Philip Morris. Ingredients added to tobacco in cigarettes manufactured by Philip Morris Limited and by other entities in the Philip Morris Group of Companies which are sold by Philip Morris Limited in Australia or imported by Philip Morris Limited into Australia. Mar 1995. Philip Morris. Bates No. 2072522939/2989. http://legacy.library.ucsf.edu/tid/aab06c00

74 Staunton D. [Recommendation 11, that a list of the ingredients in tobacco products...]. Tobacco Institute of Australia. Dec 1995. Philip Morris. Bates No. 2050755254. http://legacy.library.ucsf.edu/tid/dul79e00

75 Australia Parliament Senate Community Affairs References Committee. The tobacco industry and the costs of tobacco-related illness: report of the Senate Community Affairs References Committee. Canberra: The Committee, 1995.

76 Windholz E. Ingredients-Australian Senate Committee. 15 Dec 1995. Philip Morris. Bates No. 2050755265/5266. http://legacy.library.ucsf.edu/tid/ mul79e00

77 Chepiga T, Rees D. Worldwide country updates: trip report, International Ingredients Committee Meeting, Atlanta, Georgia, April 25, 1996. 15 May 1996. R J Reynolds. Bates No. $515550116 / 0124$. http:// legacy.library.ucsf.edu/tid/iyy90d00

78 British Columbia Ministry of Health; Canadian Council for Tobacco Control British Columbia Ministry of Health and Ministry Responsible for Seniors 1998 reports on cigarette additives and ingredients and smoke constituents, December 16, 1998. 20 Jul 1999. Philip Morris. Bates No. 2072523709/ 3710. http://legacy.library.ucsf.edu/tid/xia06c00

79 Windholz E. Tobacco Product Disclosure Roundtable Discussion, Friday, November 26, 1999. 29 Nov 1999. Philip Morris. Bates No. 2072523432/ 3437. http://legacy.library.ucsf.edu/tid/lta06c00

80 Philip Morris Limited (Australia). Letter to Australian Department of Health: draft. 29 Mar 2000. Philip Morris. Bates No. 2073278536/8622. http:// legacy.library.ucsf.edu/tid/gxi95c00

81 Commonwealth Department of Health. Voluntary agreement for the disclosure of the ingredients of cigarettes. Commonwealth Department of Health 2000. http://www.health.gov.au/pubhlth/strateg/drugs/tobacco/ agreement.pdf (Accessed 23 Sep 2002)

82 Commonwealth Department of Health. Australian cigarette ingredient information. Commonwealth Department of Health 2002. Last updated: 2 Sep 2002. http://www.health.gov.au/pubhlth/strateg/drugs/tobacco/ ingredients. htm (Accessed 2 Jun 2003)

83 Proctor C. Smoking issues. British American Tobacco Company. Sep 1994 Guildford Depository. Bates No. 502581860/1870. http://tobacco. health.usyd.edu.au/tds/BAT502581860_1870 (Accessed 2 Jun 2003)
84 Francis P. [Telex to F. Resnik] 10 Feb 1981. Philip Morris. Bates No. 2023084973. http://legacy.library.ucsf.edu/tid/mbn68e00

85 Hutchens R. Australian cigarette specifications. 2 Dec 1993. R J Reynolds. Bates No. 509609820/9820. http://legacy.library. ucsf.edu/tid/oyc73d00

86 Brindle J. Ingredient MGE-7 [Letter to J. Webb]. WD \& HO Wills (Australia) Ltd. 6 Jul 1984. Brown \& Williamson. Bates No. 620468253. http:// legacy.library.ucsf.edu/tid/pgz21 foo

87 Hackney P. ITC-14 [Material Safety Data Sheet] and ITC 14 Flavour [Fax to W. Allen, RJ Reynolds]. Rothmans of Pall Mall (Australia) Limited. 2 Nov 1993. R J Reynolds. Bates No. 509609823/9827. http:// legacy.library.ucsf.edu/tid/qyc73d00

88 King W, Borland R, Christie M. Way-out developments at BATCO. Tobacco Control 2003; 12:107-8

89 Green S. C.A.C. II-Salamander: developments in scientific field 1976/77 British-American Tobacco Company. 18 Apr 1977. British American Tobacco. Bates No. 110069827/9829. http://tobacco. health.usyd.edu.au/tds/BAT1 10069827_9829 (Accessed 29 May 2003)

90 Tully R. [Letter to M. Funck]. 25 Sep 1998. Philip Morris. Bates No. 2070478711/8715. http://legacy.library.ucsf.edu/tid/tdi08d00

91 British-American Tobacco Company. The future of expanded tobaccos. 22 Aug 1979. British American Tobacco. Bates No. 100150468/0482. hitp:// www.library.ucsf.edu/tobacco/batco/html/1500/1521/ (Accessed 27 May 2003)

92 Green S. G-13. British-American Tobacco Company. 9 Dec 1976. British American Tobacco. Bates No. 109883339/3340. hitp:// www.library.ucsf.edu/tobacco/batco/html/900/983 (Accessed 27 May 2003)

93 Willis N. Expanded tobacco G. 13-DIET. 22 Apr 1981. Brown \& Williamson. Bates No. 655007037/7064. http://legacy.library.ucsf.edu/ $\mathrm{tid} /$ our99e00

94 Davis N. Briefing note for B.D. Bramley, Esq for TSRT meeting-20th March 1989: G13 process in Singapore. 7 Mar 1989. British American Tobacco. Bates No. 502620861. http://www. library.ucsf.edu/tobacco/batco/html/ 10800/10839/ (Accessed 27 May 2003)

95 Smith H. [Letter to P. Denton]. Arjay Equipment Corporation. 20 Nov 1978. R J Reynolds. Bates No. 515586531/6533. http://legacy.library.ucsf.edu/tid/ hm+92d00

96 Wakeham H. 'No cough' cigarette-your memo of April 17. 25 Apr 1968. Philip Morris. Bates No. 1001880870. http://legacy.library.ucsf.edu/tid/ dfc $38 \mathrm{e} 00$

97 Stockwell T, Rutley R, Clark K. Pesticides and other chemicals in cigarette tobacco: an investigation into the knowledge and attitudes of Australian smokers. National Centre for Research into the Prevention of Drug Abuse. Nov 1990. British American Tobacco. Bates No. 600500122/0193. http:// www.ncth.ca/Guildford.nsf/97ed27ef6fc5e7fa852569ca006ff2c8/ 10e25cd398a6554f852569cf006693a7/\$FILE/02500469.pdf (Accessed 27 May 2003)

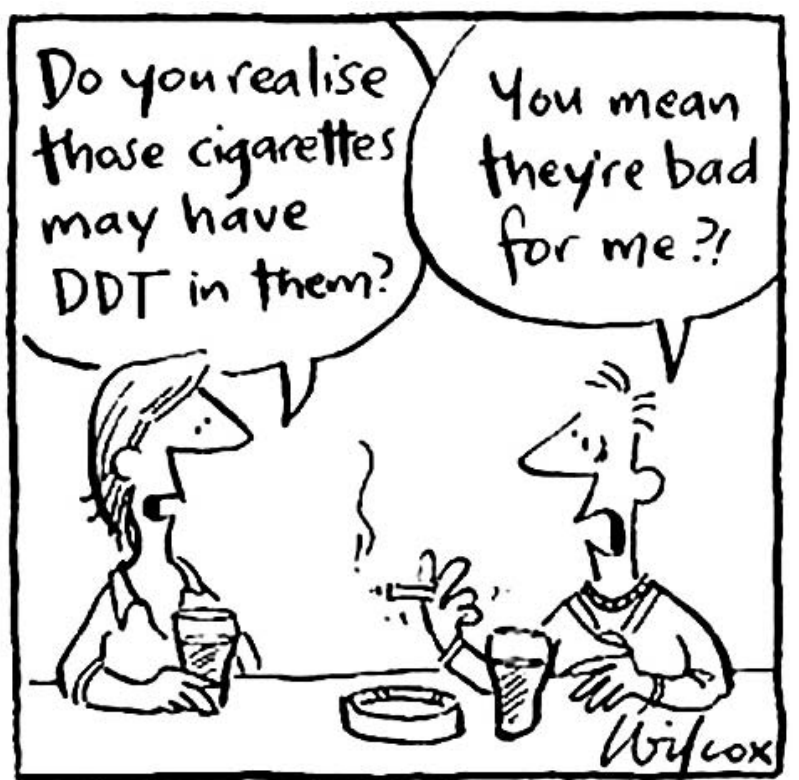

Reprinted with kind permission, Cathy Wilcox, Sydney Morning Herald. 